\title{
PERUBAHAN GARIS PANTAI DI PERAIRAN MUARA BANYUASIN KAITANNYA DENGAN SEDIMENTASI
}

\section{COASTLINE CHANGES IN BANYUASIN ESTUARY WATERS IN RELATION TO SEDIMENTATION}

\author{
M. Andrian Putra Pratama, Beta Susanto Barus*, \& Wike Ayu Eka Putri \\ Jurusan Ilmu Kelautan, FMIPA-UNSRI, Palembang, 30662, Indonesia \\ *E-mail: betasusanto@unsri.ac.id
}

\begin{abstract}
The estuary waters of the Banyuasin River are one of the river estuary waters that is affected by the sedimentation process. This area gets a big influence from land input. This study aims to analyze the changes in the coastline in Muara Banyuasin Waters, South Sumatra associated with sediment characteristics and sedimentation rates. This research was conducted in October 2018 and sampling was carried out by installing sediment traps for 14 days. Samples were taken once a week and then the rate of sediment accumulation were calculated. Analysis of coastline changes is done using image data processing with a span of 5 years using ErMapper 7.0 software. The results of image data processing are discussed descriptively with sedimentation rates and sediment characteristics. The results showed that the predominant characteristics of sediments were clay and silt with sediment accumulation rates ranging from $2.06 \mathrm{~kg} / \mathrm{m}^{2} /$ day $-6.55 \mathrm{~kg} / \mathrm{m}^{2} /$ day. The estuary waters of the Banyuasin River undergo a change in coastline in the form of sedimentation and abrasion. Sedimentation occurred at 6 stations while abrasion occurred at 2 stations. Coastline changes are ranged $\pm 33 \mathrm{~m}$ $\pm 322 \mathrm{~m}$. Stations that experience high coastline changes are characterized by high sedimentation rates and subtle dominant substrate types (silty clay). Whereas areas that experience low coastline changes have low sedimentation rates with coarser substrate types (sandy silt).
\end{abstract}

Keywords: Banyuasin estuary waters, coastline change, sedimentation

\begin{abstract}
ABSTRAK
Perairan muara Sungai Banyuasin merupakan salah satu perairan muara sungai yang dipengaruhi oleh proses sedimentasi. Perairan ini mendapatkan pengaruh besar dari masukan daratan. Penelitian ini bertujuan untuk menganalisis perubahan garis pantai di Perairan Muara Banyuasin, Sumatera Selatan yang dikaitkan dengan karakteristik sedimen dan laju sedimentasi. Penelitian ini dilaksanakan pada bulan Oktober 2018 dan pengambilan sampel dilakukan dengan memasang sedimen trap selama 14 hari. Sampel diambil 1 kali dalam 1 minggu kemudian dihitung laju akumulasi sedimen. Analisis perubahan garis pantai dilakukan menggunakan pengolahan data citra dengan rentang waktu 5 tahun menggunakan software ErMapper 7.0. Hasil pengolahan data citra dibahas secara deskriptif dengan laju sedimentasi dan karakteristik sedimen pada daerah penelitian. Hasil penelitian menunjukkan bahwa karakteristik sedimen yang mendominasi adalah dominan lempung dan lumpur dengan laju akumulasi sedimen berkisar antara $2,06 \mathrm{~kg} / \mathrm{m}^{2} / \mathrm{hari}-6,55 \mathrm{~kg} / \mathrm{m}^{2} / \mathrm{hari}$. Perairan muara Sungai Banyuasin mengalami perubahan garis pantai berupa sedimentasi dan abrasi. Sedimentasi terjadi pada 6 stasiun sedangkan abrasi terjadi pada 2 stasiun. Perubahan garis pantai berkisar $\pm 33 \mathrm{~m}- \pm 322 \mathrm{~m}$. Stasiun yang mengalami perubahan garis pantai tinggi dicirikan oleh laju sedimentasi yang tinggi dan berjenis substrat dominan lebih halus (lempung berlanau). Sedangkan daerah yang mengalami perubahan garis pantai rendah memiliki laju sedimentasi rendah dengan tipe substrat yang lebih kasar (lempung berpasir).
\end{abstract}

Kata kunci: muara Sungai Banyuasin, perubahan garis pantai, sedimentasi 


\section{PENDAHULUAN}

Pemerintah provinsi Sumatera Selatan sedang melakukan pembangunan di berbagai bidang demi berkembangnya provinsi Sumatera Selatan. Salah satunya adalah rencana reklamasi dan pembangunan pelabuhan internasional di daerah muara Sungai Banyuasin. Kawasan pelabuhan ini diharapkan menjadi alur transportasi dan aktivitas pelayaran berskala besar.

Salah satu faktor lingkungan perairan yang perlu diperhatikan adalah proses sedimentasi. Sedimentasi ini akan mengakibatkan pendangkalan yang dapat mengganggu alur transportasi dan menyebabkan perairan menjadi sulit untuk dilalui karena perubahan kedalaman perairan dan perubahan konfigurasi garis pantai baik secara vertikal maupun horizontal (Munandar \& Baeda, 2014). Sedimentasi di perairan muara Sungai Banyuasin disebabkan oleh banyak daerah sekitar daerah aliran sungai (DAS) yang dikonversi menjadi lahan pertanian. Lark et al. (2015) mengatakan bahwa lahan pertanian memiliki tingkat kerentanan yang lebih tinggi terhadap erosi. Sedimen dihasilkan oleh limpasan permukaan, dan konversi historis DAS menjadi lahan pertanian dan telah mempercepat pengiriman sedimen di luar norma geologi (Fagherazzi, 2014; Gedan et al., 2011; McKee \& Cherry, 2009; Möller et al., 2014).

Muara Banyuasin telah dilaporkan mengalami sedimentasi dari tahun ke tahun. Hartoni \& Agussalim (2007) mengatakan muara Sungai Banyuasin mengalami sedimentasi dengan laju 0,1968-3,1872 $\mathrm{kg} / \mathrm{m}^{2} /$ hari. Aritonang et al. (2016) mengatakan laju pengendapan sedimen di Pulau Anakan muara Sungai Banyuasin yaitu berkisar 2,645 x $10^{-11} \mathrm{~m}^{3} / \mathrm{s}-1,625 \times 10^{-9} \mathrm{~m}^{3} / \mathrm{s}$. Dari hasil permodelan, Pelabuhan Tanjung Api-Api perairan Muara Banyuasin mengalami penumpukan sedimentasi sebesar 0,24 m dalam 3 bulan (Teredja \& Nugroho, 2018). Pada tahun 2000-2012, Pulau Anakan muara Sungai Banyuasin mengalami penambahan garis pantai sebesar 63,80-550 m (Aritonang et al., 2016). Tujuan penelitian ini yaitu menganalisis perubahan garis pantai di Perairan Muara Banyuasin, Sumatera Selatan dikaitkan dengan karakteristik sedimen dan laju sedimentasi di daerah tersebut. Manfaat dari penelitian ini yaitu diharapkan dapat memberikan informasi mengenai perubahan garis pantai, karakteristik sedimen serta laju sedimentasi di daerah kajian sehingga bisa dimanfaatkan untuk bidang ilmu pengetahuan maupun dalam bidang-bidang lain seperti bidang konservasi laut, industri perikanan, perhubungan laut dan lain-lain.

\section{METODE PENELITIAN}

Penelitian ini dilaksanakan pada bulan Oktober 2018 di Perairan Muara Banyuasin Kabupaten Banyuasin, Provinsi Sumatera Selatan (Figure 1). Penelitian dilakukan pada 11 stasiun. Lokasi penelitian di Muara Sungai Banyuasin, secara geografis disajikan dalam Table 1.

Pengukuran arus dan pasang surut dilakukan pada 1 titik lokasi yaitu pada titik koordinat $02^{\circ} 12^{\prime} 34.3^{\prime \prime}$ LS dan $104^{\circ} 59^{\prime} 07,2^{\prime \prime}$ BT Muara Sungai Banyuasin Provinsi Sumatera Selatan. Pengolahan data arus menggunakan Surfer 9. Penentuan titik sampling dengan metode purposive sampling, sampel di stasiun 1 diambil untuk mengetahui bagaimana pergerakan transpor sedimen yang berasal dari Sungai Banyuasin. Pada stasiun 2, 3 dan 11 diambil dengan mempertimbangkan transpor sedimen yang berasal dari Sungai Lalan dan Sungai Banyuasin. Stasiun 4, 5 dan 6 diambil untuk mengetahui pengaruh transpor sedimen yang berasal dari masukan Sungai Lalan, sedangkan pada stasiun 7,8,9 dan 10 diambil untuk mengetahui bagaimana transpor sedimen yang berada di Pulau Anakan.

Pengukuran laju sedimentasi dilakukan selama 14 hari menggunakan sediment trap. Selanjutnya contoh material 


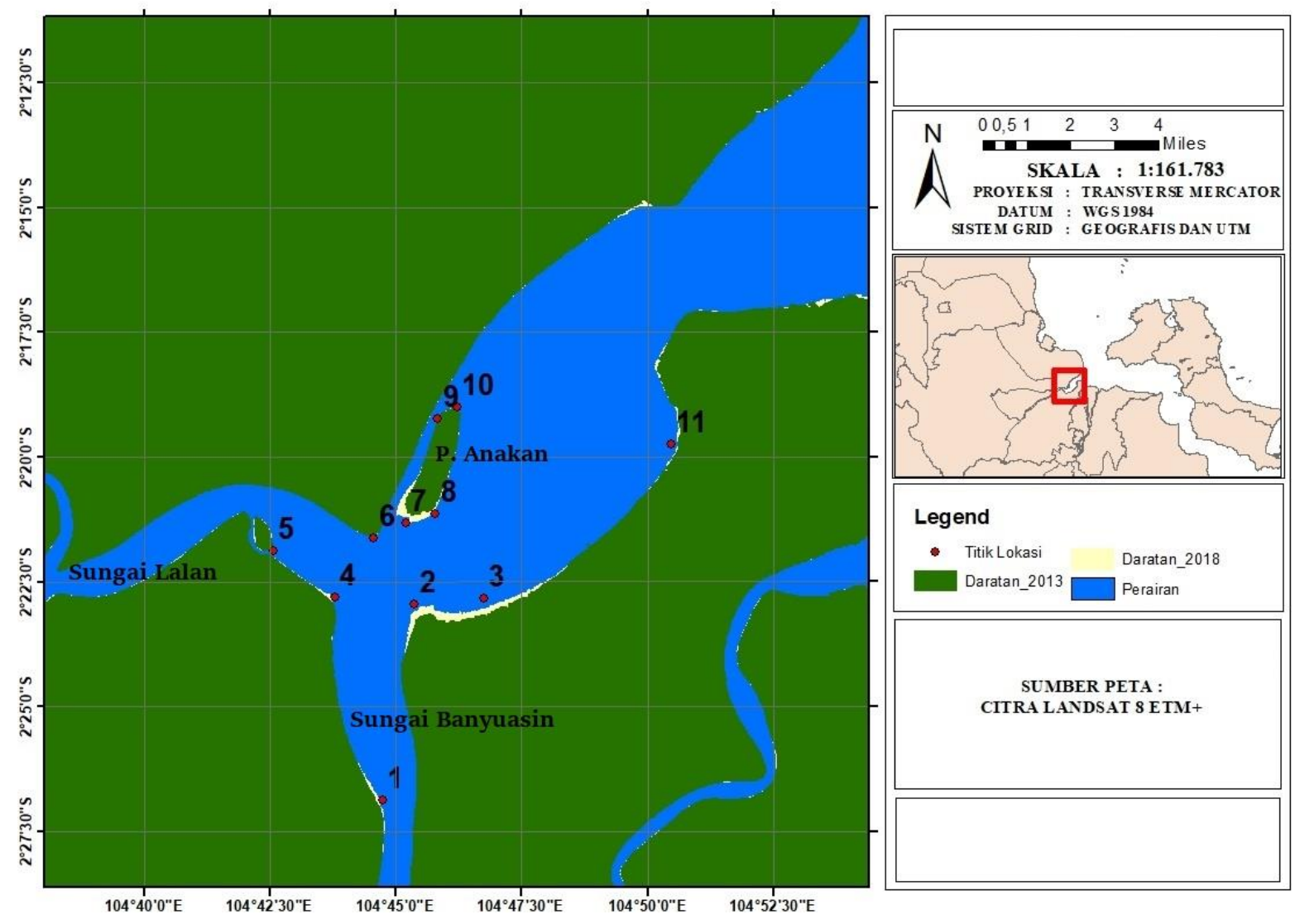

Figure 1. Research location.

Table 1. Location of station point coordinates.

\begin{tabular}{ccc}
\hline $\begin{array}{c}\text { Study } \\
\text { site }\end{array}$ & East Longitude & South Latitude \\
\hline 1 & $104^{\circ} 44^{\prime} 44,25^{\prime \prime}$ & $2^{\circ} 26^{\prime} 53,25^{\prime \prime}$ \\
2 & $104^{\circ} 45^{\prime} 22,07^{\prime \prime}$ & $2^{\circ} 22^{\prime} 57,99^{\prime \prime}$ \\
3 & $104^{\circ} 46^{\prime} 45,72^{\prime \prime}$ & $2^{\circ} 22^{\prime} 50,16^{\prime \prime}$ \\
4 & $104^{\circ} 43^{\prime} 47,62^{\prime \prime}$ & $2^{\circ} 22^{\prime} 49,30^{\prime \prime}$ \\
5 & $104^{\circ} 42^{\prime} 34,01^{\prime \prime}$ & $2^{\circ} 21^{\prime} 52,69^{\prime \prime}$ \\
6 & $104^{\circ} 44^{\prime} 34,42^{\prime \prime}$ & $2^{\circ} 21^{\prime} 37,57^{\prime \prime}$ \\
7 & $104^{\circ} 45^{\prime} 12,59^{\prime \prime}$ & $2^{\circ} 21^{\prime} 19,48^{\prime \prime}$ \\
8 & $104^{\circ} 45^{\prime} 47,68^{\prime \prime}$ & $2^{\circ} 21^{\prime} 09,02^{\prime \prime}$ \\
9 & $104^{\circ} 45^{\prime} 50,78^{\prime \prime}$ & $2^{\circ} 19^{\prime} 13,63^{\prime \prime}$ \\
10 & $104^{\circ} 46^{\prime} 13,91^{\prime \prime}$ & $2^{\circ} 19^{\prime} 00,74^{\prime \prime}$ \\
11 & $104^{\circ} 50^{\prime} 28,79^{\prime \prime}$ & $2^{\circ} 19^{\prime} 45,47^{\prime \prime}$ \\
\hline
\end{tabular}

sedimen dihitung berat kering sedimend dengan timbangan analitik. Penentuan tekstur sedimen dilakukan menggunakan saringan bertingkat (sieving) untuk fraksi pasir, kemudian ditimbang berdasarkan ukuran diameter butiran sedimen. Fraksi lumpur dianalisis menggunakan metode pipet. Data komposisi sedimen berdasarkan ukuran butir diolah menggunakan segitiga shepard untuk menentukan jenis sedimen (Rifardi, 2008). Perhitungan laju sedimentasi dilakukan dengan persamaan berikut:

$$
L S=\frac{B S}{n \cdot \pi \cdot r^{2}}
$$

Keterangan: $\quad$ LS $=$ laju sedimentasi $\left(\mathrm{g} / \mathrm{cm}^{2} /\right.$ hari $), \mathrm{BS}=$ berat kering sedimen $(\mathrm{g})$, $\pi=$ konstanta $(3,14), r=$ jari jari lingkaran sedimen trap $(\mathrm{cm}), n=$ jumlah hari pemasangan trap.

Nilai densitas didapat dengan persamaan berikut:

$$
\rho_{\text {sedimen }}=\frac{m}{v}
$$


Keterangan: $\rho$ sedimen $=$ densitas sedimen $\left(\mathrm{g} / \mathrm{cm}^{3}\right), m=$ massa jenis sedimen $(\mathrm{g}), \mathrm{v}=$ volume penambahan sedimen $\left(\mathrm{cm}^{3}\right)$.

Analisis perubahan daratan dilakukan menggunakan pengolahan data citra pada rentang waktu 5 tahun yaitu tahun 2013 dan 2018. Pengolahan data citra dilakukan dengan software ErMapper 7.0. Hasil pengolahan data citra akan dikaitkan dengan laju sedimentasi dan karakteristik sedimen pada daerah penelitian.

\section{HASIL DAN PEMBAHASAN}

\subsection{Arus dan Pasang Surut}

Hasil pengukuran menunjukkan kecepatan arus minimum sebesar 0,03 $\mathrm{m} /$ detik pada saat kondisi menuju surut terendah dan kecepatan arus maksimum adalah $0,14 \mathrm{~m} /$ detik pada saat kondisi menuju pasang tertinggi sehingga arus di Perairan Banyuasin lebih dominan arus pasang surut, yang mana kecepatan arus dan arah arus di Perairan Banyuasin bergantung pada pola pasang surut di perairan tersebut (Figure 2).

Pola pergerakan pasang surut sangat memengaruhi pergerakan arus dan

pergerakan sedimen di perairan. Pada saat kondisi surut pergerakan arus cenderung mengarah ke laut sedangkan pada saat pasang pergerakan arus cenderung mengarah masuk ke dalam sungai. Hal ini menunjukkan kondisi kecepatan arus maksimum yaitu terjadi antara jam 08:00 WIB sampai dengan 09:00 wib (pagi hari), dengan kondisi yaitu pada saat surut terendah. Hasil pengukuran pasang surut di Muara Sungai Banyuasin selama 24 jam menunjukkan bahwa tipe pasang surut di daerah tersebut adalah tipe diurnal (tunggal). Pola pasang surut yang terjadi pada daerah tersebut sangat dipengaruhi oleh masukan air laut dan pergerakan air ketika menuju pasang dan ketika menuju surut, dibutuhkan waktu 4-5 jam.

\subsection{Laju Pengendapan Sedimen}

Sedimen trap dipasang selama 14 hari pada 11 stasiun penelitian. Namun pengambilan sedimen trap dilakukan setelah 14 hari. Trap pada stasiun 1, 6 dan 9 tidak ditemukan sehingga data pada stasiun tersebut tidak didapatkan. Hasil pengukuran laju sedimentasi disajikan pada Table 2.

\section{Table 2. Density of sediment material and sedimentation rate.}

\begin{tabular}{ccc}
\hline $\begin{array}{c}\text { Study } \\
\text { site }\end{array}$ & $\begin{array}{c}\text { Density }(\rho) \\
\mathrm{g} / \mathrm{cm}^{3}\end{array}$ & $\begin{array}{c}\text { Sedimantation rate } \\
\mathrm{kg} / \mathrm{m}^{2} / \text { day }\end{array}$ \\
\hline 2 & 2.28 & 6.55 \\
3 & 2.01 & 5.36 \\
4 & 1.52 & 2.56 \\
5 & 1.35 & 2.07 \\
7 & 2.04 & 5.31 \\
8 & 1.72 & 4.90 \\
10 & 1.66 & 2.96 \\
11 & 1.74 & 5.04 \\
\hline
\end{tabular}

Proses pengendapan sedimen disebabkan oleh sifat mekanis materi tersuspensi di air atau proses pembentukan dan akumulasi sedimen pada lapisan permukaan dasar perairan (Barus et al., 2018). Laju sedimentasi di lokasi penelitian berkisar antara 2,07-6,55 kg/m²/hari dengan densitas berkisar 1,35-2,28 $\mathrm{g} / \mathrm{cm}^{3}$. Laju sedimentasi tertinggi terdapat pada stasiun 2 yaitu $6,55 \mathrm{~kg} / \mathrm{m}^{2} /$ hari dengan nilai densitas $2,28 \mathrm{~g} / \mathrm{cm}^{3}$. Stasiun 2 terletak berhadapan langsung dengan beberapa muara sungai, diantaranya Sungai Lalan dan Sungai Banyuasin. Laju sedimentasi terendah terdapat di stasiun 5 yang terletak di Sungai Lalan dan posisinya terlindung dari aliran arus. Nilai densitas pada suatu stasiun sejalan dengan laju sedimentasinya. Semakin tinggi densitas sedimen, maka semakin tinggi laju sedimentasinya. Perairan muara Sungai Banyuasin merupakan daerah yang mengalami proses sedimentasi yang tinggi akibat dari bermuaranya beberapa sungai yang membawa partikel sedimen ke muara Sungai Banyuasin. Hal ini didukung dengan pernyataan Hartoni \& Agussalim (2007) bahwa muara Sungai Banyuasin mengalami 


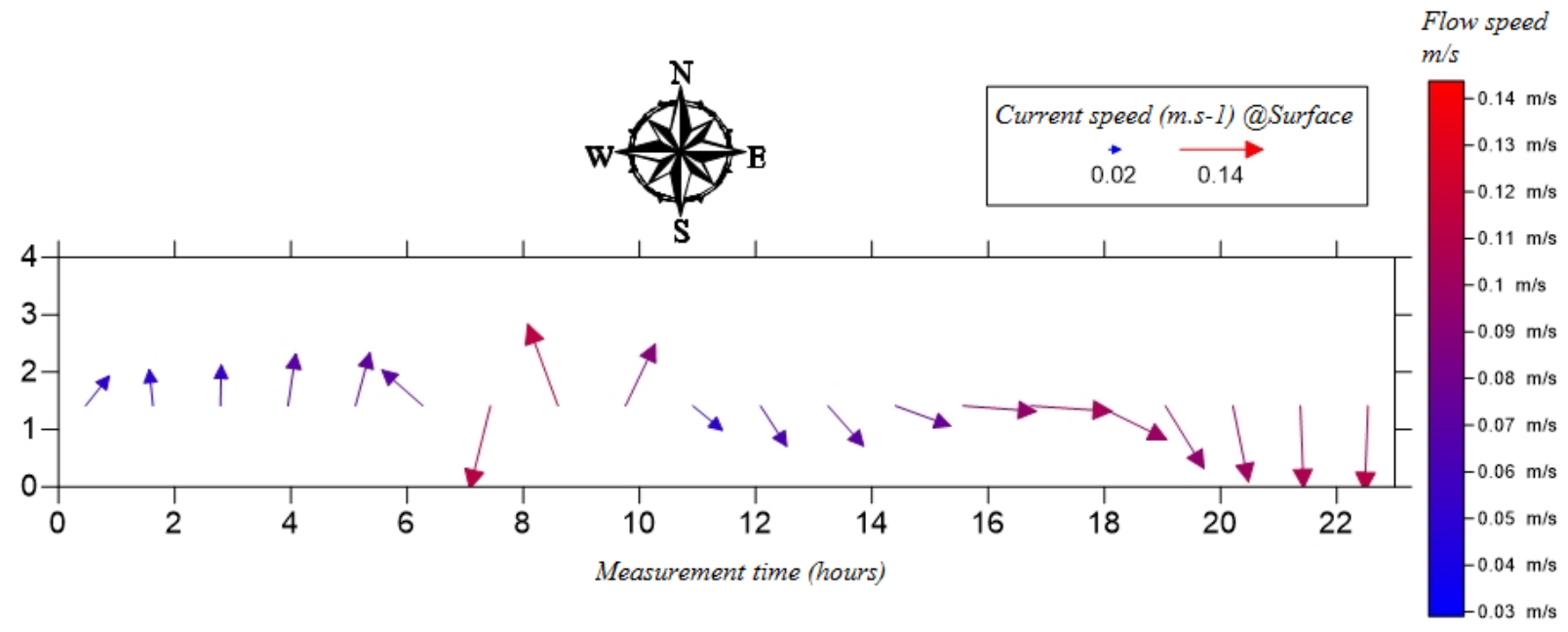

Figure 2. Stick plot current speed.

sedimentasi dengan laju 0,1968-3,1872 $\mathrm{kg} / \mathrm{m}^{2} /$ hari. Pergerakan sedimen di muara Sungai Banyuasin cenderung berjalan sesuai dengan pola arus yang ada di wilayah Perairan Banyuasin (Simbolon et al., 2015). Pola arus di muara Sungai Banyuasin dipengaruhi oleh pola pasang surut. Pada saat kondisi surut pergerakan arus cenderung mengarah ke laut sedangkan pada saat pasang pergerakan arus cenderung masuk ke dalam sungai. Hasil pengukuran menunjukkan kecepatan arus minimum sebesar 0,03 $\mathrm{m} / \mathrm{s}$ pada saat kondisi menuju surut terendah dan kecepatan arus maksimum adalah 0,14 $\mathrm{m} / \mathrm{s}$ pada saat kondisi menuju pasang tertinggi.

\subsection{Karakteristik Sedimen}

Jenis tekstur sedimen di daerah penelitian dapat dibagi menjadi 2 kelompok yaitu lempung berpasir dan lempung berlanau. Muara sungai pada umumnya memiliki jenis substrat lumpur/lempung karena adanya aliran sungai sebagai pemasok partikel-partikel kecil dari daratan (Barus et al., 2018). Stasiun 3, 5, 7, 8 dan 11 memiliki jenis tekstur sedimen lempung berpasir, sedangkan stasiun 2, 4, dan 10 memiliki jenis tekstur sedimen lempung berlanau. Data menunjukkan bahwa stasiun yang memiliki laju sedimentasi yang lebih tinggi, memiliki persentase jenis partikel halus (lempung) yang lebih tinggi juga, Selain itu, secara umum stasiun yang memiliki persentase partikel halus yang lebih tinggi memiliki nilai densitas yang juga lebih tinggi. Hal ini menandakan partikel yang lebih halus (lempung) memiliki densitas yang lebih tinggi dibandingkan pertikel yang lebih kasar (pasir dan lanau). Sebaran persentase fraksi sedimen serta jenis sedimen pada masingmasing stasiun dapat dilihat pada Table 3.

Komposisi partikel tersuspensi yang didominasi lanau dan lempung cenderung menunjukkan bahwa area tersebut dipengaruhi pergerakan arus yang lemah. Muara Sungai Banyuasin merupakan daerah yang relatif terlindung sehingga energi gerak air di lokasi ini jauh lebih rendah, sehingga sedimen (terutama) dengan ukuran yang lebih kecil/halus akan semakin mudah terendapkan (Simbolon et al., 2015). Karakteristik sedimen sangat bergantung pada jenis dan lokasi asal sumber batuan dan karakteristik proses sedimentasinya (Dewi \& Yudi, 2008).

\subsection{Perubahan Garis Pantai}

Hasil pengolahan data sedimen yang diperoleh dari alat sedimen trap dibandingkan dengan hasil dari digitasi data citra selama rentang 5 tahun untuk melihat penambahan ataupun pengurangan daratan setiap tahunnya dan dihitung penambahan daratan setiap satu minggu. Erosi dan akresi berpengaruh terhadap luasan wilayah dan 
Perubahan Garis Pantai di Perairan Muara Banyuasin . . .

Table 3. Distribution of percentage of sediment fraction and type of sediment at each station.

\begin{tabular}{ccccc}
\hline \multirow{2}{*}{ Study site } & \multicolumn{3}{c}{ Fraction (\%) } & \multirow{2}{*}{ Substrate types } \\
\cline { 2 - 4 } & Sand & Silt & Clay & \\
\hline 2 & 18.13 & 22.925 & 58.945 & Silty clay \\
3 & 20.76 & 19.15 & 60.09 & Sandy silt \\
4 & 27.09 & 28.28 & 44.63 & Silty clay \\
5 & 36.71 & 13.96 & 49.33 & Sandy silt \\
7 & 21.86 & 18.3 & 59.84 & Sandy silt \\
8 & 29.12 & 25.65 & 45.23 & Sandy silt \\
10 & 21.47 & 24.65 & 53.88 & Silty clay \\
11 & 25.58 & 10.89 & 63.53 & Sandy silt \\
\hline
\end{tabular}

lahan di kawasan pantai (Rais et al., 2004). Data citra tahun 2013 dan tahun 2018 digunakan sebagai data pendukung untuk memperkuat data hasil pengolahan laju akumulasi sedimen di perairan tersebut sebagai justifikasi keberadaan proses sedimentasi ataupun erosi. Sedimentasi dan erosi dapat menyebabkan perubahan topografi suatu wilayah estuari (Lastras et al., 2011). Down column transport material merupakan peristiwa pengendapan yang kecepatannya ditentukan dari besar kecilnya ukuran butir partikel sedimen yang diendapkan (Wibisono, 2010). Perubahan garis pantai disajikan pada Figure 3 dan Figure 4.

Berdasarkan data citra menunjukkan beberapa daerah terjadi sedimentasi dan erosi daratan. Stasiun 2 terdapat penambahan daratan melalui perubahan garis pantai \pm 322 $\mathrm{m}$ per 5 tahun atau diketahui adanya penambahan daratan $\pm 64,4 \mathrm{~m}$ per tahunnya dengan laju sedimentasi $6,55 \mathrm{~kg} / \mathrm{m}^{2} /$ hari kemudian densitas sedimen sebesar 2,28 $\mathrm{g} / \mathrm{cm}^{3}$ dengan karakteristik dominan lempung berlumpur. Pada Stasiun 2 memiliki sedimentasi paling tinggi dikarenakan banyak masukan dari beberapa mulut sungai yang diasumsikan banyak mentranspor sedimen ke lokasi tersebut. Stasiun ini terletak di mulut pertemuan muara Sungai Banyuasin dan Sungai Lalan dan memiliki luasan perairan yang cukup sempit sehingga sangat memudahkan material yang dibawa oleh kedua aliran sungai tersebut mengendap.
Keseimbangan antara sedimen yang dibawa sungai dengan kecepatan pengangkutan sedimen di muara sungai akan menentukan berkembangnya dataran pantai.

Apabila jumlah sedimen yang dibawa ke laut dapat segera diangkut oleh ombak dan arus laut, maka pantai akan dalam keadaan stabil. Sebaliknya jika jumlah sedimen melebihi kemampuan ombak dan arus laut dalam pengangkutannya, maka dataran pantai akan bertambah (Maynard et al., 2011).

Hasil pengukuran langsung diketahui secara umum wilayah perairan Muara Sungai Banyuasin memiliki kecepatan arus yang rendah yaitu berkisar 0,03-0,14 $\mathrm{m} /$ detik. Secara spesifik pada stasiun ini memiliki kecepatan arus $0,12 \mathrm{~m} /$ detik (Prianto et al., 2010). Arus yang berasal dari muara sungai membawa material sedimen menuju laut namun pada saat kecepatan arus rendah yang terjadi di utara pantai membuat pengendapan sedimen semakin tinggi. Pengendapan sedimen yang tinggi di-karenakan arus laut yang kecil tidak dapat membuat sedimen bergerak. Hal ini sesuai dengan pernyataan Komar (1998) bahwa terbentuknya sudut datang gelombang akan memengaruhi nilai arus sejajar pantai, sehingga dapat dimungkinkan sedimen dasar berpindah sepanjang pantai dan terendapkan pada daerah, oleh karena itu kecepatan arus tidak mampu lagi untuk memindahkan sedimen.

Pada stasiun 3 diketahui terjadi penambahan daratan melalui perubahan garis 


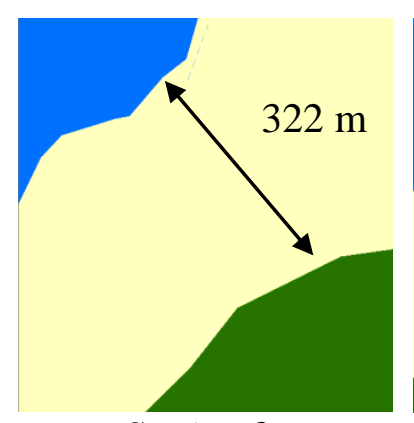

Station 2

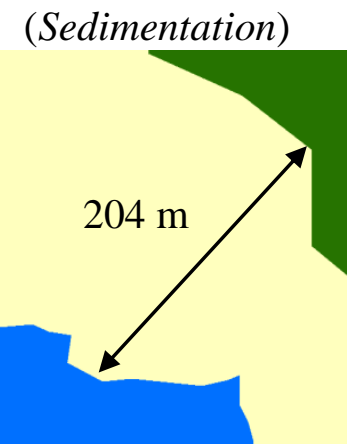

Station 7

(Sedimentation)

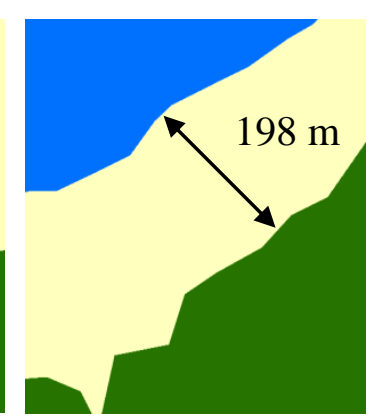

Station 3 (Sedimentation)

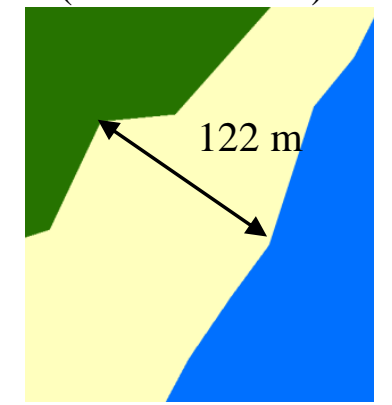

Station 8

(Sedimentation)

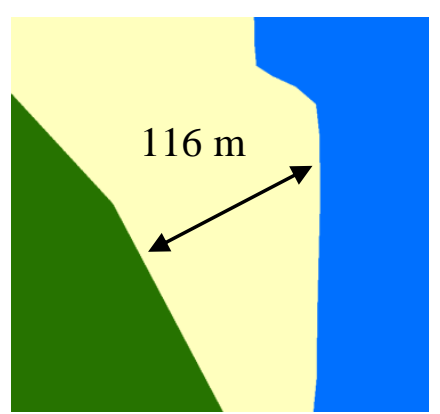

Station 4

(Sedimentation)

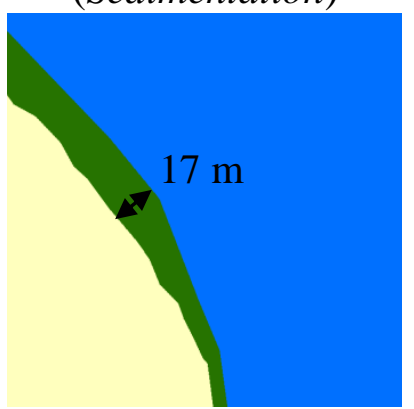

Station 10

(Abrasion)

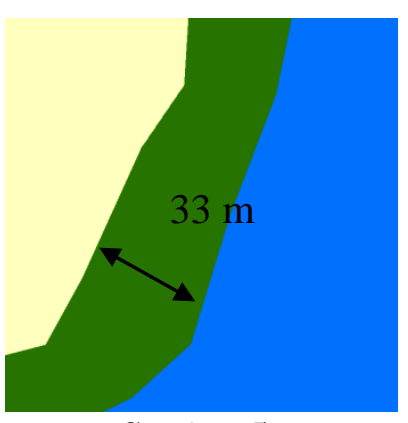

Station 5

(Abrasion)

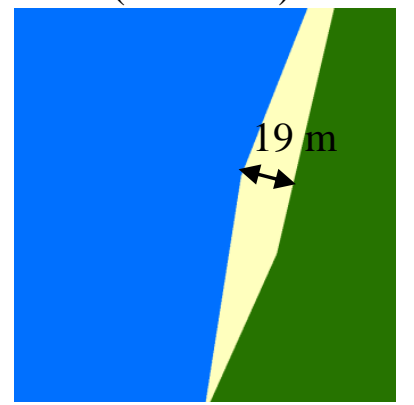

Station 11

(Sedimentation)

Information:

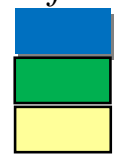

The waters

Mainland in 2013

Mainland in 2018

Figure 3. Addition (Stations 2, 3, 4, 7, 8, and 11) and reduction of land (Stations 5 and 10) at the research location.

pantai sebesar $\pm 198 \mathrm{~m}$ per 5 tahun atau $\pm 39,6$ $\mathrm{m}$ per tahun, sehingga diperoleh adanya penambahan daratan $\pm 0,76 \mathrm{~m}$ per minggu dengan laju sedimentasi sebesar 5,36 $\mathrm{kg} / \mathrm{m}^{2} /$ hari, kemudian data densitas sebesar $2,01 \mathrm{~g} / \mathrm{cm}^{3}$ dengan karakteristik sedimen lempung berpasir. Pada stasiun 3 juga terdapat sedimentasi yang cukup tinggi dikarenakan daerah trap stasiun 3 berdekatan dengan daerah trap stasiun 2 yang terletak di pertemuan dua muara sungai yaitu Sungai Banyuasin dan Sungai Lalan sehingga diasumsikan banyaknya masukan dari sungai yang banyak mentranspor sedimen ke lokasi tersebut dan mengendap. Di sepanjang Sungai Banyuasin dan Sungai Lalan banyak terdapat lahan pertanian, perkebunan dan pemukiman yang menjadi penyuplai material sedimen yang dibawa oleh arus menuju muara sungai.

Selanjutnya pada stasiun 4 berada di muara Sungai Lalan dan didapat penambahan daratan \pm 116 m per 5 tahun atau $\pm 23,2$ m per tahun sehingga didapat penambahan daratan $\pm 0,44 \mathrm{~m}$ per minggu dengan laju sedimentasi sebesar 2,56 $\mathrm{kg} / \mathrm{m}^{2} /$ hari dan data densitas sebesar $1,52 \mathrm{~g} / \mathrm{cm}^{3}$ dengan karakteristik sedimen dominan campuran lempung dan lumpur.

Pada stasiun 4 merupakan daerah yang cenderung banyak aktivitas manusia seperti pelabuhan dan transportasi di perairan dan juga berada di perairan muara Sungai Lalan sehingga bisa diasumsikan, endapan yang berada di daerah tersebut cenderung dominan berasal dari endapan sedimen di sungai Lalan bagian dalam yang dibawa oleh arus dan pasang surut (keluar) menuju 


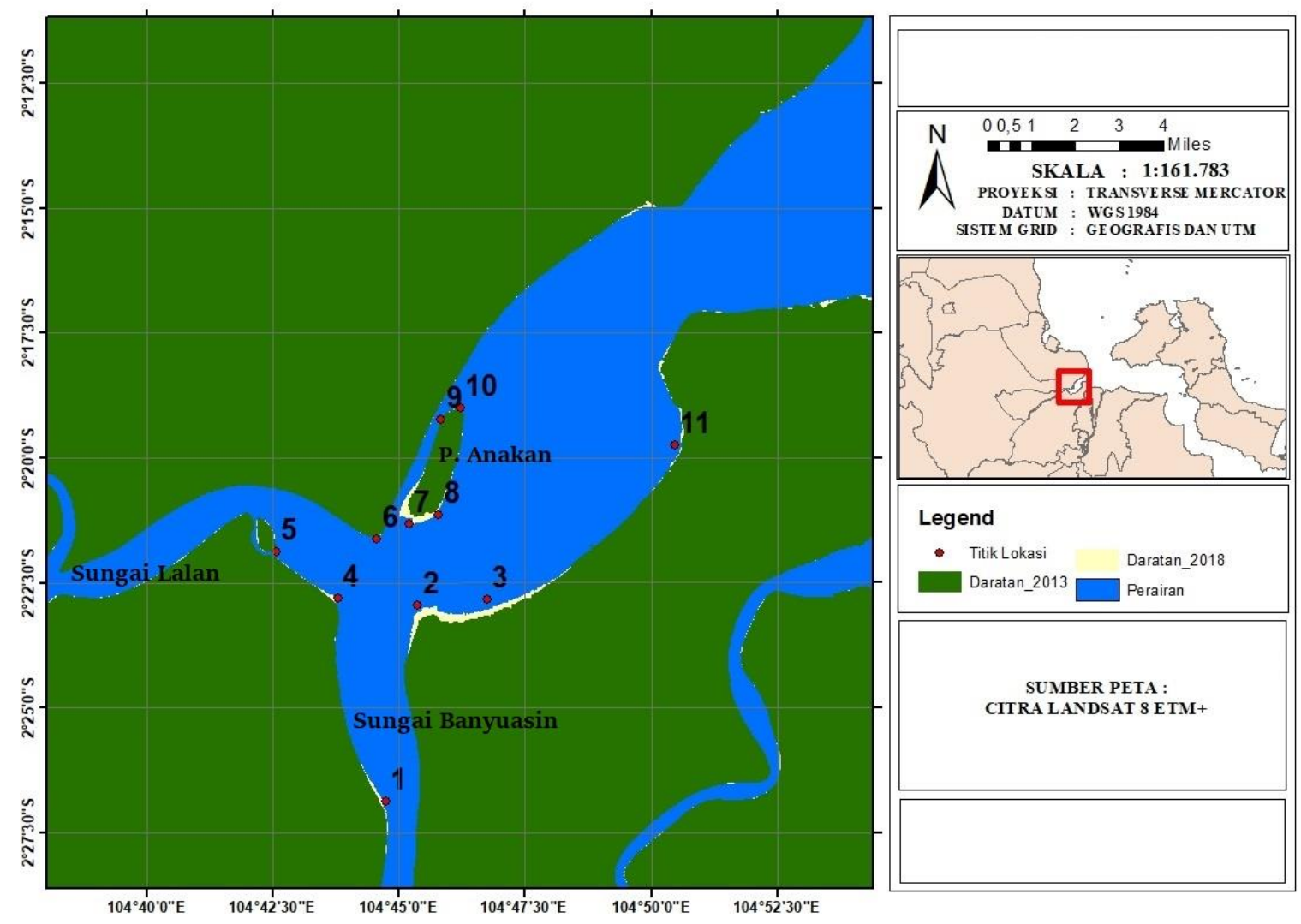

Figure 4. Changing coastline at the location point.

muara dan kemudian mengendap. Satriadi \& Widada (2004) menyatakan bahwa arus dan pasang surut menyebabkan pengadukan sedimen di dasar perairan sehingga partikel sedimen tersuspensi di dalam air. Perairan Muara Sungai Banyuasin memiliki kecepatan arus yang rendah yaitu berkisar 0,03-0,14 $\mathrm{m} /$ detik sehingga memudahkan material yang dibawa oleh kedua aliran sungai tersebut terendapkan.

Stasiun 5 berada hampir berdekatan dengan stasiun 4 yaitu di muara Sungai Lalan dan pada analisis citra didapat pengurangan daratan akibat erosi \pm 33 m per 5 tahun atau $\pm 6,6 \mathrm{~m}$ per tahun sehingga didapat pengurangan daratan akibat erosi $\pm 0,12 \mathrm{~m}$ per minggu dengan laju akumulasi sebesar 2,07 $\mathrm{kg} / \mathrm{m}^{2} /$ hari dan densitas sedimen sebesar 1,35 $\mathrm{g} / \mathrm{cm}^{3}$ dengan karakteristik sedimen dominan campuran lempung dan lumpur. Pada stasiun 7 berada di ujung Pulau Anakan di dekat muara Sungai Lalan dan muara Sungai Banyuasin dan berdasarkan hasil analisis citra didapat penambahan daratan $\pm 204 \mathrm{~m}$ per 5 tahun atau $\pm 40,8 \mathrm{~m}$ per tahun sehingga didapat penambahan daratan $\pm 0,78 \mathrm{~m}$ per minggu dengan laju sedimentasi sebesar 5,31 $\mathrm{kg} / \mathrm{m}^{2} /$ hari dan densitas sedimen sebesar 2,04 $\mathrm{g} / \mathrm{cm}^{3}$ dengan karakteristik sedimen dominan yaitu lempung berlumpur. Pada stasiun 7 merupakan daerah yang berada di Pulau Anakan yang mana pulau tersebut mengalami penambahan daratan yang cukup tinggi dari tahun ke tahun. Hal ini disebabkan karena stasiun 7 terletak di depan muara Sungai Banyuasin dan Sungai Lalan. Perairan yang terletak di depan muara sungai memiliki tingkat sedimentasi yang lebih tinggi (Nicolodi et al., 2013).

Kemudian pada stasiun 8 berada di arah barat Pulau Anakan yang menghadap langsung ke Sungai Banyuasin dan berdasarkan hasil analisis citra didapat penambahan daratan \pm 122 m per 5 tahun atau $\pm 24,4 \mathrm{~m}$ per tahun sehingga didapat penambahan daratan $\pm 0,47 \mathrm{~m}$ per minggu 
dengan laju sedimentasi sebesar 4,90 $\mathrm{kg} / \mathrm{m}^{2} /$ hari dan densitas sedimen sebesar 1,72 $\mathrm{g} / \mathrm{cm}^{3}$ dengan karakteristik sedimen dominan yaitu dominan lempung berlumpur. Sedimentasi di suatu perairan sangat dipengaruhi oleh jenis substrat yang terdapat di daerah tersebut (Ziervogel \& Bohling, 2003) dan ada atau tidaknya konsolidasi sedimen oleh zat polimetri ekstraseluler (Tolhurst et al., 2002). Satriadi (2012) yang menyatakan pada daerah pantai yang didominasi oleh sedimen pasir besarnya ukuran butir pada daerah tersebut cenderung resisten terhadap gerakan arus sehingga tidak terangkut mengikuti kecepatan dan arah arus.

Stasiun 10 berada di utara Pulau Anakan di Sungai Banyuasin dan berdasarkan hasil analisis citra didapat pengurangan daratan akibat erosi $\pm 17 \mathrm{~m}$ per 5 tahun atau $\pm 3,4 \mathrm{~m}$ per tahun sehingga didapat pengurangan daratan akibat erosi $\pm 0,06 \mathrm{~m}$ per minggu dengan laju sedimentasi sebesar 2,96 $\mathrm{kg} / \mathrm{m}^{2} /$ hari dengan densitas sedimen sebesar $1,66 \mathrm{~g} / \mathrm{cm}^{3}$. Stasiun 10 berada di daerah yang mengalami pengurangan daratan akibat erosi, yang mana daerah trap stasiun 10 langsung berhadapan dengan perairan lepas dan diasumsikan arus di daerah tersebut cukup cepat sehingga endapan sedimen terus terbawa ke arah selatan Pulau Anakan.

Stasiun 11 berada hampir berdekatan dengan stasiun 3 dan pada analisis citra didapat penambahan daratan $\pm 19 \mathrm{~m}$ per 5 tahun atau $\pm 3,8 \mathrm{~m}$ per tahun, sehingga didapat pengurangan daratan akibat erosi $\pm 0,07 \mathrm{~m}$ per minggu dengan laju sedimentasi sebesar $4,34 \mathrm{~kg} / \mathrm{m}^{2} /$ hari dan densitas sedimen sebesar $1,74 \mathrm{~g} / \mathrm{cm}^{3}$ dengan karakteristik sedimen dominan yaitu lempung berlumpur. Pada stasiun ini laju sedimen yang didapat cukup tinggi sedangkan pada hasil analisis citra daerah ini hanya sedikit mengalami penambahan daratan. Hal ini dikarenakan pada daerah sekitar tempat diletakkan trap ini terdapat aktivitas transportasi pelayaran. Stasiun ini terletak di dekat pelabuhan Tanjung Api-Api sehingga diasumsikan endapan hasil aktivitas pelayaran terbawa arus kemudian mengendap di daerah tersebut.

Laju akumulasi sedimen tertinggi yang didapat adalah pada stasiun 2 yaitu sebesar $6,55 \mathrm{~kg} / \mathrm{m}^{2} /$ hari. Penambahan daratan tertinggi terdapat di stasiun 2 dan stasiun 7 yaitu sebesar $322 \mathrm{~m}$ dan $204 \mathrm{~m}$. Pada stasiun 2 diasumsikan bahwa pergerakan arus dan gelombang cukup tenang sehingga banyaknya partikel sedimen seperti lempung dan lanau yang terperangkap pada sedimen trap dan beberapa aktivitas manusia seperti pertanian dan pemukiman disepanjang daerah aliran sungai yang menjadi sumber partikel sedimen akan dibawa dan diendapkan di lokasi tersebut. Stasiun 7 terletak di Pulau Anakan yang mengarah ke pertemuan Sungai Banyuasin dan Sungai Lalan, sehingga sedimen yang berasal dari dua sungai tersebut tertahan di daerah tersebut. Stasiun 7 juga terlindung dari arus dan gelombang yang berasal dari laut. Aritonang et al. (2014) mengatakan kecepatan arus sekitar Pulau Anakan muara Sungai Banyuasin sangat lambat yaitu menyentuh angka minimum $0 \mathrm{~m} / \mathrm{detik}$, sehingga dimungkinkan untuk sedimen dengan ukuran butir kecil atau halus terperangkap.

Gelombang permukaan dapat menyentuh permukaan sedimen ketika kedalaman air (d) lebih kecil dari setengah panjang gelombang (Kristensen et al., 1992; Hofmann et al., 2011). Ukuran partikel sedimen juga sangat memengaruhi proses sedimentasi di suatu lokasi. Rifardi (2008) menyatakan sedimen ukuran kasar akan mengendap tidak jauh dari sumbernya pada daerah sekitar mulut sungai, sebaliknya semakin jauh dari mulut sungai maka porsi partikel yang lebih besar yang diendapkan akan semakin sedikit. Dasar perairan yang didominasi oleh partikel sedimen kasar menggambarkan perairan tersebut dipengaruhi oleh arus yang kuat dan begitu pula sebaliknya jika didominasi oleh partikel halus maka perairan dalam kondisi tenang 
dan arus lemah. Kondisi ini sesuai dengan kondisi arus permukaan Perairan Banyuasin yang tergolong lambat (Simbolon et al., 2015) dan didominasi oleh karakteristik sedimen lempung berlumpur. Arus yang lambat atau lemah akan lebih didominasi oleh partikel yang lebih halus karena pengadukan atau pencampuran sedimen berlangsung lambat.

\section{KESIMPULAN}

Perairan muara Sungai Banyuasin mengalami perubahan garis pantai berupa sedimentasi dan abrasi. Sedimentasi terjadi pada 6 stasiun sedangkan abrasi terjadi pada 2 stasiun. Perubahan garis pantai oleh sedimentasi tertinggi terdapat pada stasiun 2 dengan penambahan daratan $\pm 322 \mathrm{~m}$ dan perubahan daratan oleh abrasi terdapat pada stasiun 5 dengan pengurangan daratan \pm 33 $\mathrm{m}$. Stasiun yang mengalami perubahan garis pantai tertinggi dicirikan oleh laju sedimentasi yang tertinggi dan berjenis substrat dominan lebih halus (lempung berlanau). Sedangkan daerah yang mengalami perubahan garis pantai terendah memiliki laju sedimentasi yang rendah dengan tipe substrat yang lebih kasar (lempung berpasir).

\section{UCAPAN TERIMA KASIH}

Terima kasih kepada Lembaga Penelitian dan Pengabdian Masyarakat (LPPM) Universitas Sriwijaya yang telah memberikan Hibah Penelitian dan semua pihak yang telah berkontribusi sehingga penelitian ini dapat dilaksanakan.

\section{DAFTAR PUSTAKA}

Aritonang, A.E., H. Surbakti, \& A.I.S. Purwiyanto. 2016. Laju pengendapan sedimen di Pulau Anakan muara Sungai Banyuasin, Sumatera Selatan. J. Maspari, 6(2): 133-141. https://doi.org/10.36706/maspari.v8i1 .2645
Barus, B.S., T. Prartono, \& D. Soedarma. 2018. Keterkaitan sedimentasi dengan persen tutupan terumbu karang di perairan Teluk Lampung. J. Ilmu dan Teknologi Kelautan Tropis, 10(1): 4957.

http://doi.org/10.29244/jitkt.v10i1.18 719

Dewi, T. \& D. Yudi. 2008. Partikel mikroskopis dasar laut nusantara. Pusat Penelitian dan Pengembangan Geologi Kelautan. Bandung. 96 p.

Fagherazzi, S. 2014. Coastal processes: storm-proofing with marshes. National Geoscience, 7: 701-702. http://doi.org/10.1038/ngeo2262

Gedan, K.B., M.L. Kirwan, E. Wolanski, E.B. Barbier, \& B.R. Silliman, 2011. The present and future role of coastal wetland vegetation in protecting shorelines: answering recent challenges to the paradigm. Climate Change, 106: 7-29. http://doi.org/10.1007/s10584-0100003-7

Hartoni \& A. Agussalim. 2007. Laju sedimen tersuspensi di wilayah pembangunan pelabuhan Tanjung Api-Api muara Sungai Banyuasin Kabupaten Banyuasin. J. Penelitian Sains, 10(2): 204-211. https://doi.org/10.36706/jps.v10i2.44 1

Hofmann, H., A. Lorke, \& F. Peeters. 2011. Wind and ship wave-induced resuspension in the littoral zone of a large lake. Water Resources Research, 47: 1995-2021. http://doi.org/10.1029/2010WR01001 2

Kristensen, P., M. Søndergaard, \& E. Jeppesen, 1992. Resuspension in a shallow eutrophic lake. Hydrobiologia, 228: 101-109. http://doi.org/10.1007/BF00006481

Komar, P.D. 1998. Beach processes and sedimentation. Second Edition. Printice Hall. New Jersey. 544 p. 
Lark, T.J., J.M. Salmon, \& H.K. Gibbs. 2015. Cropland expansion outpaces agricultural and biofuel policies in the United States. Environment Restore Letter, 10(4): 1-11.

http://doi.org/10.1088/1748-

9326/10/4/044003

Lastras, G., M. Canals, D. Amblas, C. Lavoie, I. Church, B. De Mol, R. Duran, A.M. Calafat, J.E. HughesClarke, C.J. Smith, \& S. Heussner. 2011. Understanding sediment dynamics of two large submarine valleys from seafloor data: Blanes and La Fonera canyons, northwestern Mediterranean Sea. Marine Geology, 280: 20-39.

http://doi.org/10.1016/j.margeo.2010. 11.005

Maynard, C., J. McManus, R.M.M. Crawford, \& D. Paterson, 2011. A comparison of shortterm sediment deposition between natural and transplanted saltmarsh after saltmarsh restoration in the Eden Estuary (Scotland). Plant Ecology \& Diversity, 4(1): 103-113. http://doi.org/10.1080/17550874.2011 .560198

McKee, K.L. \& J.A. Cherry. 2009. Hurricane Katrina sediment slowed elevation loss in subsiding brackish marshes of the Mississippi River Delta. Wetlands, 29: 2-15. http://doi.org/10.1672/08-32.1

Möller, I., M. Kudella, F. Rupprecht, T. Spencer, M. Paul, B. van Wesenbeeck, K. Wolters, G. Jensen, K. Bouma, T.J. Miranda-Lange, \& M.S. Schimmels. 2014. Wave attenuation over coastal salt marshes under storm surge conditions. National Geoscience, 7: 727-731. http://doi.org/10.1038/ngeo2251

Munandar. F. \& A. Baeda. 2014. Kajian laju transport sedimen di Pantai Akkarena. J. Lingkar Widyaiswara, 1(1): 10-18.
Nicolodi, J.L., E.E. Todo Jr., \& L. Farina, 2013. Dynamics and resuspension by waves and 6 sedimentation pattern definition in low energy environments. Guaíba Lake (Brazil). Brazilian J. of Oceanography, 61: 5564. http://doi.org/10.1590/S167987592013000100006

Prianto, E., Husnah, \& S. Aprianti. 2010. Karakteristik fisika kimia perairan dan struktur komunitas zooplankton di estuari Sungai Banyuasin, Sumatera Selatan. J. Bawal, 3(3): 149-157.

http://doi.org/10.15578/bawal.3.3.201 $0.149-157$

Rais, J., B. Sulistyo, S. Diamar, T. Gunawan, M. Sumampouw, T.A. Soeprapto, I. Suhardi, A. Karsidi, \& M.S. Widodo. 2004. Menata ruang laut Terpadu. PT. Pradnya Paramita. Jakarta. 251 p.

Rifardi. 2008. Tekstur sedimen sampling dan analisis. UNRI Press. Pekanbaru. 101 p.

Satriadi, A. \& S. Widada. 2004. Distribusi muatan padatan tersuspensi di muara Sungai Bodri, Kabupaten Kendal. J. Ilmu Kelautan, 9(2): 101-107. http://doi.org/10.14710/ik.ijms.9.2.10 $1-107$

Satriadi, A. 2012. Studi batimetri dan jenis sedimen dasar laut di Perairan Marina, Semarang, Jawa Tengah. Buletin Oseanografi Marina, 1: 5362.

http://doi.org/10.14710/buloma.v1i5.6 917

Simbolon, F., H. Surbakti, \& Hartoni. 2015. Analisis pola sebaran sedimen tersuspensi menggunakan teknik penginderaan jauh di perairan muara Sungai Banyuasin. J. Maspari, 7(2): $1-10$. https://doi.org/10.36706/maspari.v7i2 .2432

Teredja, K.W. \& E.O. Nugroho. 2018. Penanganan sedimentasi di Pelabuhan Tanjung Api-Api pada Sungai 
Banyuasin Provinsi Sumatera Selatan. J. Reka Racana, 20(10): 117-126. https://doi.org/10.26760/rekaracana.v $4 \mathrm{i} 3.117$

Tolhurst, T.J., G. Gust, \& D.M. Paterson, 2002. The influence of an extracellular polymeric 2 substance (EPS) on cohesive sediment stability. Proceedings in Marine Science, 5(3): 409-425.

http://doi.org/10.1016/S15682692(02)80030-4

Wibisono, M.S. 2010. Pengantar llmu kelautan. Jakarta: Penerbit Universitas Indonesia. Jakarta. 253 p.
Ziervogel, K. \& B. Bohling, 2003. Sedimentological parameters and erosion behaviour of submarine coastal sediments in the southwestern Baltic Sea. Geo-Marine Letters, 23: 43-52. http://doi.org/10.1007/s00367-0030123-4

Received : 11 December 2019

Reviewed :04 January 2020

Accepted :09 March 2020 